Journal Of Metallurgical Engineering And Processing Technology, Vol. 2,

No. 2, February 2022, pp. 11-20

P-ISSN: 2723-6854, E-ISSN: 2798-1037

\title{
DRY STACKING SEBAGAI METODE PENANGANAN TAILING PENGGANTI TAILING DAM
}

\author{
Frideni Yushandiana P.G.F. ${ }^{1}$, Fadlila Rahmawati ${ }^{2}$ \\ E-mail : frideni_gf@yahoo.com ${ }^{1}$; fadlila.rahma21@gmail.com ${ }^{2}$ \\ Program Studi Teknik Metalurgi - Fakultas Teknologi Mineral \\ UPN "Veteran" Yogyakarta \\ Jl. Padjadjaran, Condongcatur, Yogyakarta 55283
}

\section{Intisari}

Hasil akhir dari proses ekstraksi emas adalah konsentrat yang berupa bullion emas serta hasil sampingan berupa tailing yang ditampung dalam tailing dam. Proses pengelolaan tailing menggunakan tailing dam kurang efektif karena terbatasnya lahan dan kebutuhan air yang berlebihan. Oleh karena itu diperlukan analisis metode pengganti, salah satunya adalah metode dry stacking. Penulisan jurnal ini menggunakan studi literatur yang berkaitan dengan tema dan tujuan dari penulisan jurnal. Metode dry stacking memiliki kelebihan yaitu kontaminasi air tanah rendah, penggunaan lahan sedikit, resiko kecelakaan akibat aktivitas seismik rendah, jangka waktu maintenance alat yang panjang, mendukung recovery logam berharga dalam tailing, dan dapat meminimalisir kehilangan air proses. Namun, metode ini memiliki kekurangan yaitu biaya proses tinggi, skala produksi rendah, perlu sistem rembesan yang kompleks, tidak adanya sistem penampungan air, dan perlunya uji mineralogi dan geokimia lebih lanjut. Dari analisa yang dilakukan, metode dry stacking efektif untuk menggantikan tailing dam sebagai metode pengelolaan tailing dengan beberapa hal yang harus diperhatikan dan dikembangkan terkait instalasi fondasi yang konsisten dengan kriteria deformasi tertentu yang diterima pada kondisi pemuatan yang statis dan dinamis untuk mencapai proses yang optimal dan ekonomis.

Kata kunci : emas, tailing dam, dry stacking

\begin{abstract}
The end result of the gold extraction process is a concentrate in the form of gold bullion and a byproduct in the form of tailings which is stored in the tailings dam. The tailings management process using a tailings dam is less effective due to limited land and excessive water requirements. Therefore, it is necessary to analyze alternative methods, one of which is the dry stacking method. This journal is written using literature studies related to the themes and objectives of journal writing. The dry stacking method has advantages, namely low groundwater contamination, low land use, low risk of accidents due to seismic activity, long equipment maintenance period, supports recovery of valuable metals in tailings, and can minimize process water losses. However, this method has drawbacks, namely high processing costs, low production scale, the need for a complex seepage system, the absence of a water storage system, and the need for further mineralogy and geochemical tests. From the analysis carried out, the dry stacking method is effective to replace tailings dam as a tailings management method with several things that must be considered and developed regarding the installation of foundations that are consistent with certain deformation criteria accepted under static and dynamic loading conditions to achieve an optimal and economical process.
\end{abstract}

Keyword : gold, tailing dam, dry stacking

\section{PENDAHULUAN}

Indonesia merupakan negara dengan sumber daya alam yang melimpah, baik yang dapat diperbaharui maupun tidak dapat diperbaharui. Salah satu sumber

daya alam tidak diperbaharui yang memiliki nilai ekonomi tinggi adalah emas. Dikutip dari ceicdata.com, produksi emas Indonesia dilaporkan 
sebesar $130.000 .000 \mathrm{~kg}$ pada tahun 2020.

Setiap tahun selalu ada tailing sisa pengolahan yang dialirkan menuju tailing dam dimana limbah membutuhkan area yang luas karena jumlahnya yang banyak dan membutuhkan waktu yang lama untuk dapat mengendap sampai airnya dapat digunakan kembali untuk proses, akibatnya area pengendapan menjadi terbatas. Selain itu, penggunaan dam membutuhkan jumlah air yang besar agar terjadi pengendapan tetapi dalam prosesnya banyak air yang hilang akibat merembes ke rongga tanah serta menguap akibat panas matahari. Dari masalah tersebut, dapat dicari metode lain yang dapat menjadi solusi, dimana hal tersebut sesuai dengan tujuan dari tulisan ini, yaitu untuk membahas metode dry stacking yang dapat digunakan sebagai metode penanganan tailing pengganti tailing dam.

\section{METODOLODI PENELITIAN}

Penelitian ini dilaksanakan melalui studi pustaka terhadap berbagai literatur yang berkaitan dengan tema dan tujuan penelitian terkait metode dry stacking sebagai metode penanganan tailing pengganti tailing dam.

\section{HASIL DAN PEMBAHASAN}

Salah satu penggunaan metode $d r y$ stacking adalah Skouries project di perusahaan Eldorado Gold. Terdapat beberapa keuntungan penggunaan dry stacking oleh perusahaan Eldorado Gold seperti yang disampaikan dalam press release yaitu :
1. Bahan tumpuk kering lebih padat daripada tailing konvensional dan dapat ditumpuk dan dipadatkan, sehingga menempati lebih sedikit ruang dan mengurangi jejak lingkungan fasilitas hingga $50 \%$.

2. Kandungan padatan yang tinggi dari material dry stacking, yang memiliki konsistensi serupa dengan pasir basah, secara signifikan meningkatkan keamanan dan stabilitas fasilitas tailing, terutama selama kejadian cuaca ekstrem.

3. Air yang dipisahkan dari tailing akan didaur ulang, sehingga mengurangi kebutuhan untuk mengambil air dari sumber lokal.

4. Memungkinkan reklamasi berkelanjutan, membuat reklamasi akhir di akhir masa pakai tambang lebih cepat dan lebih mudah.

Perusahaan lain yang menggunakan metode dry stacking adalah PT Citra Palu Minerals (CPM). Proses utama yang digunakan yaitu :

1. Penyaringan

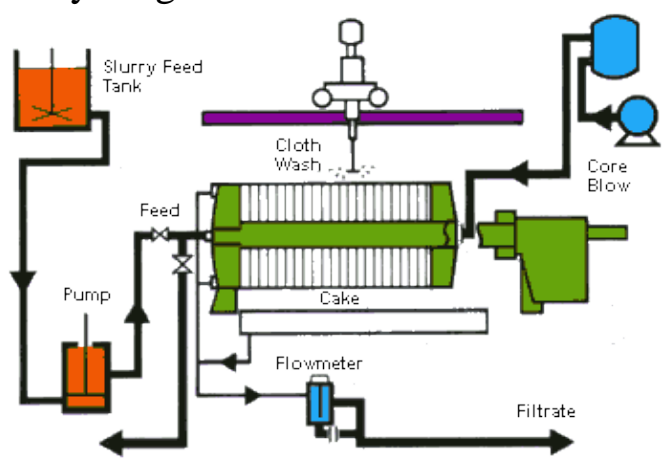

Gambar 3.1 filter pressed

Sumber : http://www.solidliquidseparation.com/

Sistem pengelolaan air pada pabrik pengolahan CPM dilakukan secara closed-circuit. Produk sampingan berupa tailing mengalir secara gravitasi ke buffer tank yang 
Journal Of Metallurgical Engineering And Processing Technology, Vol. 2,

No. 2, February 2022, pp. 11-20

P-ISSN: 2723-6854, E-ISSN: 2798-1037

merupakan tempat penyimpanan tail slurry. Slurry kemudian dialirkan menuju filter press yang bertujuan untuk memisahkan padatan dan air.

Proses filtrasi bertujuan untuk menggantikan proses pengendapan pada metode tailing dam yang terjadi secara alami sehingga membutuhkan waktu lama.

Filtrasi tailing dapat dilakukan menggunakan mesin filter pressed yang didalamnya terdapat tumpukan plate yang ditutupi dengan filter berupa clothes. Umpan yang berupa limbah tailing dipompa melalui pipa yang ada pada bagian tengah filter hingga memenuhi plate, air dan udara dialirkan melalui saluran lain untuk memberikan tekanan 3-10 atm. Solution akan melewati clothes dan keluar melalui kran pada plate sedangkan padatan akan tertahan pada permukaan clothes. Proses akan dihentikan ketika solution sudah tidak bisa melewati filter karena telah dipenuhi oleh padatan.

Proses filtrasi menghasilkan tailing kering dengan kadar air 20\%, sehingga $80 \%$ air proses akan dikembalikan ke pabrik pengolahan atau tangki proses untuk digunakan kembali dalam proses pengolahan emas. Jumlah air yang digunakan kembali dari filter press ke pabrik pengolahan tercatat sebanyak 75.726 $\mathrm{m}^{3}$. Tailing yang dihasilkan dalam bentuk material yang kokoh dengan kompresibilitas rendah dan konduktivitas hidrolik rendah.
2. Penumpukan

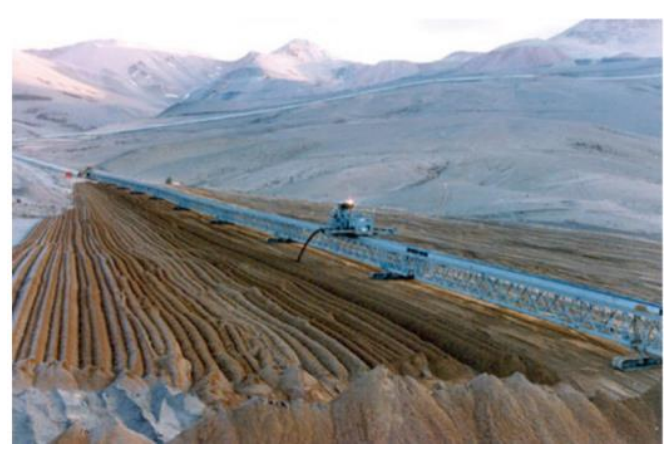

Gambar 3.2 Proses pengangkutan dan penumpukan dry tailing Sumber : Industry.gov.au

Filter dibersihkan dari padatan yang tertahan dengan cara diketok atau dikerok. Padatan ini sudah tidak mungkin dipindahkan menggunakan pipa karena memiliki persen solid tinggi meskipun tidak sepenuhnya kering, oleh karena itu digunakan alat belt conveyor. Padatan dipindahkan kemudian disusun pada area terbuka atau area bekas tambang dan lama kelamaan akan memadat.Penyimpanan tailing menggunakan metode tailing dam menimbulkan tantangan sosial, lingkungan, dan keselamatan yang substansial, sebagaimana dibuktikan oleh bencana yang disebabkan oleh runtuhnya bendungan tailing.

Terdapat beberapa pertimbangan mengenai penggantian metode tailing dam dengan dry stacking sebagai metode pengelolaan tailing yaitu:

1. Kontaminasi air tanah

Penggunaan bendungan rawan terjadi rembesan dari air limbah sehingga fondasi terkontaminasi yang berdampak pada air tanah serta rembesan dapat mematikan vegetasi disekitar kolam pengendapan. Pada metode dry stacking, air dihilangkan sebelum tailing ditumpuk sehingga 
Journal Of Metallurgical Engineering And Processing Technology, Vol. 2,

No. 2, February 2022, pp. 11-20

P-ISSN: 2723-6854, E-ISSN: 2798-1037

meminimalkan rembesan air pada area penyimpanan.

2. Penggunaan Lahan

Penggunaan lahan pada metode $d r y$ stacking sangat sedikit karena proses pengendapan yang seharusnya membutuhkan lahan yang luas digantikan dengan proses filtrasi sehingga lokasi yang dibutuhkan dapat diminimalisir dan sesuai apabila lokasi penampungan limbah terbatas.

Dry tailing dapat ditumpuk pada lereng lembah, pondasi yang lebih rendah, dan lokasi bekas penambangan yang sudah habis masa penambangan.

3. Rehabilitasi lahan

Lokasi penumpukan tidak menimbulkan bekas yang besar seperti pada tailing dam. Hal ini mendukung proses rehabilitasi karena mengurangi risiko dan kewajiban penutupan. Tailing yang ditumpuk akan ditempatkan pada liner, direklamasi di atasnya dengan tanah dan vegetasi asli.

Tailing akan direklamasi secara bertahap, tidak sekaligus atau disebut reklamasi progresif. Lokasi dry stacking seperti di Green Creek Mining dimana lokasi penumpukan yang beroperasi sejak tahun 1980an telah tereklamasi sebagian yang ditunjukkan dengan permukaan yang ditumbuhi rumput.

\section{Risiko Kecelakaan}

Area dengan aktivitas seismik tinggi sering menyebabkan masalah serius pada penggunaan tailing dam karena seringkali konstruksi tanggul penahan jebol atau terjadi rembesan ketika terjadi gempa. Tailing kering dipadatkan untuk menciptakan struktur rekayasa yang stabil sehingga kemungkinan terjadi kegagalan bencana dan erosi rendah. Pada bagian bawah penyimpanan tailing kering terdapat tanggul disusun dari batu yang memberikan stabilitas tambahan selama peristiwa seismik besar untuk mencegah geseran tumpukan.

5. Perbaikan Alat

Perbaikan alat secara progresif mudah dilakukan dan dilakukan dalam jangka waktu yang lebih lama sehingga biaya perawatan lebih rendah bila dibandingkan dengan fasilitas penyimpanan konvensional.

6. Nilai Recovery

Logam yang terlarut dalam solution dapat direcovery karena air hasil filter akan dikembalikan ke sirkuit proses.

7. Biaya Maintenance

Proses filter pressed pada metode dry stacking membutuhkan biaya tinggi untuk pengoperasian serta perbaikan alat filter pressed yang prinsip kerjanya seperti alat filter pada merril crowe namun dalam skala yang lebih besar karena input yang lebih besar.

8. Daur Ulang Air

Tailing dam membutuhkan biaya pengelolaan dalam jangka waktu lama, bahkan setelah proses produksi selesai dimasa mendatang. Penghematan finansial dapat dilakukan dengan memotong biaya operasional melalui daur ulang air limbah untuk dikembalikan ke proses. Seperti percobaan yang dilakukan oleh perusahaan instalasi teknologi dry stacking, FLSmidth, proses 
Journal Of Metallurgical Engineering And Processing Technology, Vol. 2,

No. 2, February 2022, pp. 11-20

P-ISSN: 2723-6854, E-ISSN: 2798-1037

ekstraksi dengan kapasitas 100.000 tpd membutuhkan air lebih dari 200.000 tpd pada proses thickening. Hampir 50\% air proses hilang ketika proses pengendapan limbah pada tailing dam. Dengan penggunaan filter pressed, kehilangan air dapat diminimalisir dan dana dapat dihemat $\$ 2,5 /$ ton.

9. Skala produksi

Metode dry stacking biasanya beroperasi pada kapasitas produksi yang rendah karena biaya peralatan dan manajemen operasional pabrik penyaringan yang besar, sehingga untuk pabrik dengan skala besar diperlukan kajian biaya lebih lanjut agar tetap ekonomis.

10. Sistem Rembesan

Tailing yang telah diolah dan setengah kering akan ditumpuk dan dipadatkan dimana hal tersebut menurunkan porositas dari tumpukan sehingga diperlukan manajemen kontur permukaan untuk mencegah akumulasi dan pembuangan air permukaan penyebab genangan serta erosi tumpukan.

11. Penampungan Air

Proses dry stacking tidak menyediakan fasilitas penyimpanan air sehingga tidak dapat digunakan sebagai penampungan sementara atau tadah hujan dimana air tersebut seharusnya dapat menjadi cadangan ketika memasuki musim kemarau.

12. Uji Mineralogi dan Geokimia Pengujian dilakukan untuk mengetahui kandungan yang dapat bereaksi dengan udara seperti sulfida. Oksidasi sulfida menyebabkan air rembesan memiliki konsentrasi tinggi (tetapi volume rendah) yang biasa disebut air asam tambang. Untuk mencegah oksidasi sulfida, dapat dilakukan proses detoksifikasi.

Fasilitas dry stacking membutuhkan fondasi yang konsisten serta kriteria deformasi tertentu yang diterima pada kondisi pemuatan yang statis dan dinamis sehingga dalam instalasinya harus memperhatikan beberapa faktor berikut :

1. Pengelolaan Kualitas Air Limbah

Upaya yang dilakukan adalah pengaplikasian kolam pengolahan limbah. Air yang melalui kolam ini telah melalui proses pengelolaan pada fasilitas detoksifikasi dan polishing pond. Mulai tahun 2020, CPM memiliki titik penaatan air limbah pada titik penaatan CP 01 Poboya. Untuk menjaga agar air limbah sudah memenuhi baku mutu air sebelum dikembalikan ke badan air, perlu dilakukan suatu pengukuran rutin berdasarkan parameter uji kualitas air yang sesuai dengan peraturan yang berlaku. Air limbah yang telah memenuhi baku mutu kemudian dialirkan menuju creek kering di sekitar dry TMF. Selama tahun 2020, jumlah air limbah kegiatan pengolahan yang telah dilepaskan ke creek ini tercatat sebanyak $298 \mathrm{~m}^{3}$.

2. Pengelolaan Air Limpahan

Pemindahan air ke hulu diperlukan untuk mencegah genangan fasilitas dry stacking. Untuk mencegah rembesan pada penyimpanan tailing, sistem pelapis ganda, yang terdiri atas lapisan high-density polyethylene (HDPE), pendeteksi kebocoran, dan lapisan geosynthetic clay liner 
(GCL), dipasang di permukaan penyimpanan tailing.

Air kontak (air yang terkontaminsi tailing atau berasal dari tailing) dialirkan melalui saluran primary rock dengan lebar 10 meter yang disusun membentang di sepanjang dasar tengah lembah untuk mengontrol drainase di dalam tumpukan tailing. Penyusunan saluran ini harus memperhatikan peristiwa hidrologi yang terjadi pada lokasi stacking. Air yang dikumpulkan di kolam dan tempat penampungan biasanya digunakan kembali untuk proses atau dipompa ke instalasi pengolahan air.

Air non kontak (air permukaan alami dan air tanah dari daerah tangkapan air di sekitarnya yang belum bersentuhan dengan tailing) dikelola menggunakan sistem collection and diversion dimana air dialihkan dan dikumpulkan. Air yang terkumpul di sekitar lokasi tidak boleh dialirkan ke lokasi stacking sehingga perlu dipasang sistem pipa yang berfungsi mengalirkan air yang terkumpul pada ujung area tanggul untuk diarahkan menuju down-valley (Kwan, 2011).

Apabila proses filtrasi dapat dioptimalkan sehingga kadar air target dapat tercapai dan pemadatan dapat dilakukan dengan tepat, maka pembuatan sistem pengelolaan air yang kompleks dapat diabaikan sehingga dapat difokuskan pada penurunan kemiringan lokasi penumpukan untuk mencegah erosi.

3. Penentuan Lokasi

Lokasi penumpukan diusahakan jauh dari runoff water. Pertimbangan lokasi utama lainnya adalah terhindar dari area berangin agar debu tidak berterbangan, menghindari penempatan area pembuangan air tanah kecuali sistem drainase bawah yang cukup kuat dan dipelihara, mengoptimalkan pengangkutan dari pabrik filtrasi dimana tailing sudah jenuh dan tidak dalam kondisi slurry, serta lokasi dimana timbunan batuan sisa dapat dibuang bersama tailing kering.

Proses filtrasi tidak seluruhnya mencapai target kadar air yang diinginkan sehingga tailing tidak bisa diangkut dan ditumpuk. Untuk mengatasi hal tersebut, dapat dibangun area penyimpanan dekat pabrik filtrasi sehingga bahan dapat dengan mudah dimasukkan kembali ke proses filtrasi untuk penyimpanan permanen di tumpukan kering.

4. Uji Tailing

Pengujian yang biasanya dilakukan untuk menyusun tahapan proses adalah :

- Tahap Pra-kelayakan : approximate tailings gradation and mineralogy, flask or similar filtrate testing, standard proctor (moisture-density), dan vendor engagement - filtration and transportation

- Tahap Kelayakan : tempe cell laboratory testing, geochemical testwork, bench scale filtration testing, extended moisture density work, dan transport behavior evaluation.

- Tahap Rekayasa : variable moisture testwork dan possible field compaction trial 
Journal Of Metallurgical Engineering And Processing Technology, Vol. 2,

No. 2, February 2022, pp. 11-20

P-ISSN: 2723-6854, E-ISSN: 2798-1037

5. Kadar Air

Kadar air dari tailing yang dicapai bergantung pada teknologi penyaringan yang digunakan, kesesuaian antara jenis tailing dan teknologi yang digunakan, serta karakteristik fisik tailing. Standar yang digunakan untuk mengukur kadar air pada tailing adalah kadar air target harus setara dengan kadar air optimum Standard Proctor tailing yang berkisar antara $10-20 \%$.

Tailing yang telah dilakukan filtrasi biasanya mengalami penambahan ukuran akibat pemadatan pada clothes filtrat, mungkin ketetapan target moisture harus disesuaikan.

6. Zona Fasilitas

Iklim yang kering diserta kondisi tailing yang disimpan dalam keadaan tidak jenuh membuat material lebih mudah terbawa udara dan menjadi debu yang berbahaya bagi kesehatan lingkungan apabila tidak ditangani dengan benar.

Instalasi dry stacking di lingkungan dengan curah hujan tinggi dapat menimbulkan masalah untuk lalu lintas peralatan pengangkutan dan pemadatan.

Kedua masalah tersebut dapat diatasi dengan penggunaan pipe belt conveyor dan penggunaan atap pada bagian atas stacker pad.

7. Stabilitas Lereng

Analisis stabilitas lereng perlu mempertimbangkan beberapa hal untuk mencegah erosi yaitu :

- Kekuatan geser tailing, fondasi, rockfill, dll.

- Terdapat permukaan air yang statis. Faktor permukaan air bukan hal yang fatal kecuali tailing harus dipertahankan dalam kondisi kering.

- Peristiwa seismik yang terjadi pada lokasi penumpukan harus diperhatikan kaitannya dengan proses longsor saat penumpukan dan juga rehabilitasi pascapenutupan. Dilatansi material memiliki pengaruh yang signifikan terhadap kekuatan material terhadap aktivitas seismik.

8. Kompresibilitas

Kompresibilitas dari tailing berpengaruh terhadap laju penumpukan. Filtered tailing biasanya merupakan material tidak jenuh dengan saturasi $50-70 \%$. Semakin dalam letak penumpukan tailing maka tekanan atau kompresibilitas pada tailing semakin tinggi sehingga porositasnya juga menurun seperti pada grafik berikut.

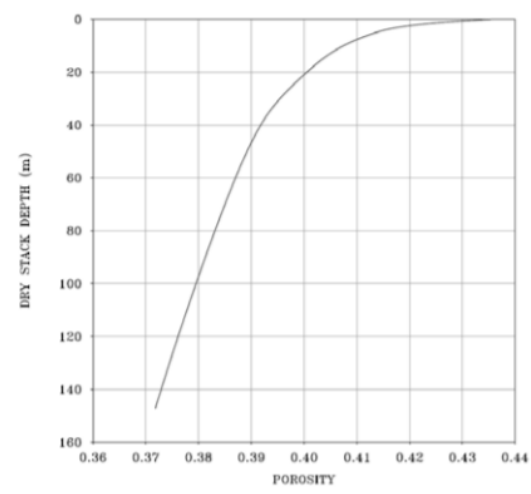

Gambar 3.3 Hubungan porositas dengan kedalaman tumpukan tailing Sumber : J. Lupo \&, J. Hall (2010) 


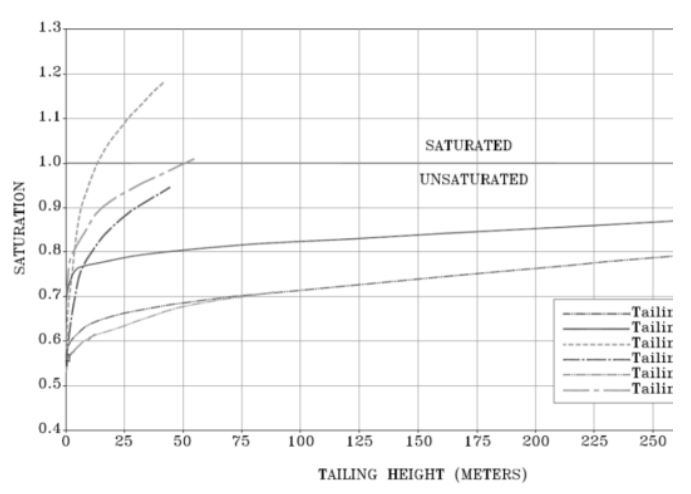

Gambar 3.4 Saturation versus tailing height

Sumber : J. Lupo \&, J. Hall (2010) Adanya saturasi dan/atau tekanan air pori berlebih dalam dry stacking, dapat menimbulkan masalah stabilitas. Dengan melihat grafik pada gambar 3.4 maka dapat diperkirakan tinggi tumpukan tailing maksimal agar tidak terjadi kelebihan tekanan atau kompresibilitas pada tumpukan.

9. Laju Penumpukan

Apabila ditumpuk dengan laju tinggi, tailing dengan sifat kompresibilitas tinggi dapat menghasilkan tekanan pori yang berlebihan sehingga menyebabkan tumpukan tidak stabil. Hal ini dapat diatasi dengan membuat banyak titik pendistribusian sehingga dapat tersebar secara merata ke seluruh lokasi penumpukan. Selain itu, lokasi penumpukan dapat dilakukan pada lokasi cekungan untuk mengatasi tailing dengan shear strength rendah. Metode ini mudah untuk dikonstruksi namun perlu adanya kajian mengenai biaya dan jadwal pengawasan.

10. Pengangkutan dan Penempatan Dry Tailing Kering

Biaya pengelolaan fasilitas $d r y$ stacking sangat dipengaruhi oleh jarak angkut, strategi penempatan, upaya pemadatan, upaya penutupan, dan reklamasi.

Penempatan di fasilitas dapat dengan sistem stacker radial conveyor sehingga penempatan tailing dilakukan dengan conveyor yang dapat bergerak disepanjang lokasi stacking. Penggunaan conveyor pada iklim kering dapat menyebabkan material terbawa angin yang dapat diatasi dengan penggunaan pipe belt conveyor seperti dijelaskan pada poin 8 diatas.

Pengangkutan juga dapat dilakukan menggunakan truk, namun biasanya terkendala pada penyediaan jalur transportasi. Pada lokasi basah, tumpukan tailing yang tidak terlalu kering, serta daerah dengan aktivitas seismik tinggi menyebabkan pemadatan berjalan lambat sehingga jalur menjadi basah dan sulit dilalui truk.

\section{KESIMPULAN}

Metode dry stacking memiliki kelebihan dalam aspek kontaminasi air tanah, luasan penggunaan lahan, risiko kecelakaan akibat aktivitas seismik, perbaikan alat, nilai recovery logam terlarut, biaya maintenance, dan daur ulang air. Namun, metode ini memiliki kekurangan yang harus menjadi perhatian yaitu skala rembesan, pembuatan sistem rembesan, penampungan air, uji mineralogi dan geokimia, serta pengaruh iklim dan cuaca.

Dari analisis kekurangan dan kelebihan, metode dry stack tailing sesuai digunakan untuk penanganan tailing pengganti tailing dam pada 
perusahaan dengan keterbatasan lokasi penyimpanan karena solid pada tailing telah dipisahkan dari solution dengan filter pressed sehingga penyimpanan $d r y$ tailing dapat dilakukan pada lokasi yang lebih kecil atau lahan bekas penambangan sebagai upaya awal rehabilitasi lahan. Dry stacking dinilai lebih aman untuk wilayah dengan aktifitas seismik tinggi. Selain itu, metode dry stacking dapat meminimalisir kehilangan air selama proses akibat penguapan dan rembesan yang dapat mengkontaminasi air tanah.

Dengan instalasi yang sesuai dengan design guidelines serta adanya berbagai pengujian seperti mineralogi, instalasi alat dan penumpukan, dan skala filtrasi dengan jumlah besar, penggunaan dry stack tailing sebagai pengganti tailing dam dapat dilakukan.

\section{UCAPAN TERIMAKASIH}

Ucapan terima kasih yang sebesarbesarnya penulis sampaikan kepada:

1. Ibu Frideni Yushandiana P.G.F. sebagai dosen pembimbing dalam penulisan makalah ini.

2. Ibu Anggia Magnalita Octaviani selaku pembimbing dari PT NHM bidang project metallurgist.

3. Berbagai pihak yang telah ikut berpartisipasi membantu kelancaran kegiatan penelitian, baik secara langsung maupun tidak langsung.

\section{DAFTAR PUSTAKA}

(2021, April 29). News Release : Eldorado Gold Receives Approval for Use of Dry Stack Tailings at Skouries. Vancouver : Eldorado Gold
(2015). FLSmidth Dry Tails Stacking Solutions. Dikutip dari https://video.flsmidth.com/flsmidt h-dry-tails-stacking

. (2016). Pengelolaan Tailing : Praktik Kerja Unggulan dalam Program Pembangunan Berkesinambungan untuk Industri Pertambangan. Australia : Australian Governmen

Accioly, Antonio \& McCaslin, Mick \& Misra, B. (2017). Dry Stack Tailings? Don't Bother With Filters - A Case Study.

BumiResourcesMinerals. (2020). Laporan Keberlanjutan PT Bumi Resources Minerals Tbk. Dikutip dari

https://bumiresourcesminerals.co $\underline{\mathrm{m} /}$

Caldwell, Jack A. \& Crystal, Colleen. (2015). Filter-pressed tailings facility design, construction, and operating guidelines. Canada : Robertson GeoConsultants

Davies, Michael \& Rice, S.. (2001). An alternative to conventional tailings management-dry-stack fi ltered tailings. In Proceedings Tailings and Mine Waste '01. 411-420.

Davies, Michael. (2018). Filtered Dry Stacked Tailings-The Fundamentals Conference Paper. Canada: AMEC Environment \& Infrastructure

Fajar, Fabima, dkk. (2017). Pengelolaan Limbah Tailing. Dikutip dari https://www.academia.edu/35395 754/Pengelolaan_Limbah_Tailing

Gainau, Rio Jecson. (2019). Analisis Perkembangan Tanah pada Tailing dam TSF 56 PT. Nusa Halmahera Mineral Maluku Utara di Area Suksesi Alam. Yogyakarta: Master 
Journal Of Metallurgical Engineering And Processing Technology, Vol. 2, No. 2, February 2022, pp. 11-20

P-ISSN: 2723-6854, E-ISSN: 2798-1037

Thesis UPN "Veteran"
Yogyakarta

Kwan, etc. (2011). Design of the Eldorado Gold Efemçukuru Filtered Tailings Facility. Proceedings Tailings and Mine Waste 2011

Lupo, J.F., \& Hall, J.E. (2010). Dry stack tailings - design considerations.

Sarempa, A., \& Isjudarto, A. (2016). Optimasi Recovery Emas dan Perak Dengan Sianidasi Pada Deposit Bijih Emas Kadar Rendah Di PT.Nusa Halmahera Minerals Daerah Gosowong Kabupaten Halmahera Utara, Provinsi Maluku Utara. 